\title{
Arginine Is Synthesized From Proline, Not Glutamate, in Enterally Fed Human Preterm Neonates
}

\author{
CHRIS TOMLINSON, MAHROUKH RAFII, MICHAEL SGRO, RONALD O. BALL, AND PAUL PENCHARZ
}

\begin{abstract}
Department of Paediatrics [C.T., M.S., P.P.], Research Institute [C.T., M.R., P.P.], The Hospital for Sick Children, Toronto, Ontario M5G1X8, Canada; Department of Nutritional Sciences [C.T., M.S., P.P.], University of Toronto, Toronto, Ontario M5S3E2, Canada; Department of Paediatrics [M.S.], St Michael's Hospital, Toronto, Ontario M5B1W8, Canada; Department of Agricultural, Food and Nutritional Science [R.O.B., P.P.], University of Alberta, Edmonton, Alberta T6G2P5, Canada
\end{abstract}

\begin{abstract}
In neonatal mammals, arginine is synthesized in the enterocyte, with either proline or glutamate as the dietary precursor. We have shown several times in piglets that proline is the only precursor to arginine, although in vitro evidence supports glutamate in this role. Because of this uncertainty, we performed a multitracer stable isotope study to determine whether proline, glutamate, or both are dietary precursors for arginine in enterally fed human neonates. Labeled arginine $(\mathbf{M}+2)$, proline $(\mathbf{M}+1)$, and glutamate $(\mathbf{M}+3)$ were given enterally to 15 stable, growing preterm infants (GA at birth 30-35 wk) at 1-3 wk postnatal age. Enrichment in urine of the tracer amino acids and the $\mathrm{M}+1$ and $\mathrm{M}+3$ isotopomers of arginine were measured by LC-tandem mass spectrometry to determine the contribution of proline and glutamate to arginine synthesis. Plateau enrichments of arginine and proline tracers were measurable in urine. Urinary glutamate enrichment was not detected. Conversion of proline to arginine was detected. However, the $\mathrm{M}+3$ isotopomer of arginine, which would have been synthesized from glutamate, was not detected. We conclude that, in contrast to the current consensus in the literature based on in vitro studies, proline is the major contributor to arginine synthesis in human preterm infants. (Pediatr Res 69: 46-50, 2011)
\end{abstract}

$\mathrm{I}^{\mathrm{n}}$ most mammals, including humans, arginine is considered a conditionally indispensable amino acid that may become an essential component of diet during times of maximal growth or critical illness, e.g. burn injury (1-3). An infant will receive $\sim 45 \mathrm{mg} / \mathrm{kg} / \mathrm{d}$ of arginine from human milk (4); however, assuming $2 \mathrm{~g} / \mathrm{kg} / \mathrm{d}$ net protein accretion, healthy neonates require at least $140 \mathrm{mg} / \mathrm{kg} / \mathrm{d}$ for protein synthesis alone; therefore, a high rate of arginine synthesis is implied.

In infants requiring neonatal intensive care, it is clear that arginine is an essential dietary amino acid. This has been demonstrated by the observation that infants receiving total parenteral nutrition (TPN) deficient in arginine developed hyperammonemia that was responsive to arginine infusion $(5,6)$. Infants in intensive care have hypoargininemia compared with healthy infants (7), and arginine deficiency has been investigated in the development of necrotizing enteroco-

Received May 10, 2010; accepted August 10, 2010

Correspondence: Paul B. Pencharz, M.B., Ch.B., Ph.D., F.R.C.P.C., Division of Gastroenterology and Nutrition, The Hospital for Sick Children, University of Toronto, 555 University Avenue, Toronto, Ontario, Canada M5G 1X8; e-mail: paul.pencharz@sickkids.ca

Supported by Grant MOP12928 from the Canadian Institutes for Health Research.

Some of the results presented in this study were presented in abstract form at Experimental Biology 2008. litis (NEC) (8) and pulmonary hypertension (9). Furthermore, arginine supplementation was shown to reduce the incidence of all stages of NEC in moderately at risk infants (10) and a single bolus infusion of i.v. arginine improved oxygenation in infants with pulmonary hypertension (11). Therefore, because arginine is clearly important for metabolism in the neonate, it is critical to understand the metabolic pathways involved in its synthesis.

The process for arginine synthesis in the adult involves an intestinal-renal axis. Citrulline is synthesized in the enterocyte either from glutamate via P5C synthase or from proline via proline oxidase (12). Citrulline is then released to the portal venous system; it is not taken up by the liver but by the kidney (13) where it is converted to arginine via argininosuccinic acid using the enzymes argininosuccinate synthase (ASS) and argininosuccinate lyase (ASL; Fig. 1).

However, in neonatal mammals, the process of arginine synthesis takes place entirely within the gut; the enterocyte has low arginase in the neonatal period and the proximal tubule of the kidney, where citrulline is converted to arginine in the adult, has low ASS and ASL (7). When this mechanism of neonatal arginine synthesis converts to the intestinal-renal axis of adults or what mediates the change is not clear. It is also unclear whether proline or glutamate is the main precursor for arginine synthesis in the neonate because there are conflicts in the literature between the results reported using in vivo versus in vitro methods.

By using the neonatal pig model, our laboratory has shown that arginine is synthesized from enteral proline and is able to ameliorate an arginine deficient diet (14). Furthermore, we have shown that the ability of proline to act as a precursor for arginine is dependent on normal intestinal function (15). There was negligible synthesis of arginine from glutamate whether it was given enterally or parenterally $(14,16)$. When fed an arginine-deficient diet, intestinal synthesis was increased but not at a rate sufficient to meet metabolic demands (16). Similarly, in piglets fed with a proline-deficient diet, arginine was converted to proline, but the arginine label was not detected in glutamate, although it was present in ornithine and citrulline (17). Conversely, in vitro work using piglet entero-

Abbreviations: ASL, argininosuccinate lyase; ASS, argininosuccinate synthase; MPE, mole percent excess 


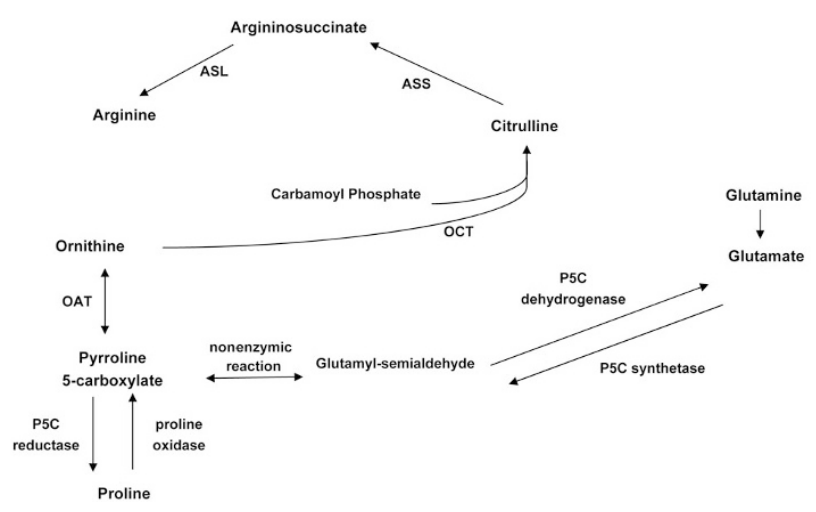

Figure 1. Pathway of arginine synthesis. ASL (EC-4.3.2.1), ASS (EC6.3.4.5), OAT, ornithine aminotransferase (2.1.6.13), OCT, ornithine carbamoyl transferase (2.1.3.3), P5C reductase (1.5.1.2), proline oxidase (1.5.99.8), P5C dehydrogenase (1.5.1.12), and P5C synthetase (EC-not assigned).

Table 1. Patient details

\begin{tabular}{lccl}
\hline & Mean & Range & SD \\
\hline GA at birth (completed wks) & 32.6 & $30-35$ & \pm 1.5 \\
Birth weight (kg) & 1.75 & $1.0-2.16$ & \pm 0.32 \\
Age at study (d) & 2.7 & $7-21$ & \pm 1.8 \\
Weight at study (kg) & 1.85 & $1.48-2.25$ & \pm 0.25 \\
Weight change (kg) & 0.1 & $-0.05-0.45$ & \pm 0.18 \\
\hline
\end{tabular}

$\mathrm{n}=5$.

cytes has shown that glutamate is a significant precursor of arginine (18). Recent studies in fasting adults also showed significant conversion of $2-{ }^{15} \mathrm{~N}$ glutamine to arginine and citrulline (19). However, the use of a ${ }^{15} \mathrm{~N}$-labeled tracer makes these results difficult to interpret because any of the nitrogen atoms in arginine may be derived ultimately from the amino nitrogen of glutamine or glutamate or both.

By using a multitracer stable isotope design, we sought to determine the ability of the human neonate to synthesize arginine and its immediate biochemical precursors, citrulline and ornithine, from the potential dietary precursors proline and glutamate.

\section{METHODS}

Subjects. Fifteen low-birth weight infants were recruited from the nursery at St. Michael's Hospital, Toronto. Infants were eligible for the study if they were between 30 and 34 wk GA, $<21$ d old, and fully enterally fed with either formula or expressed breast milk. The infants were not receiving respiratory support or i.v. medications and had no congenital anomalies. The clinical characteristics of the infants are summarized in Table 1. At the time of the study, all infants were receiving $160 \mathrm{~mL} / \mathrm{kg} / \mathrm{d}$ of either expressed breast milk and fortifier or formula (Enfamil). Informed written consent was obtained from one or both parents. The study was approved by the Research Ethics Boards at The Hospital for Sick Children and St. Michael's Hospital, Toronto.

Study design. All infants received three labeled amino acids, which were given enterally either orally or via nasogastric (NG) tube. As all infants were fully fed and did not have venous access, it was not possible to use i.v. tracers. Infants were given a priming dose, and to simulate a constant infusion, this was followed immediately and subsequently by further equal boluses of labeled amino acids every 2 or $3 \mathrm{~h}$ depending on the feeding protocol (20). To ensure complete delivery of the labeled amino acids, they were given immediately before feeds through the NG tube or in a bottle nipple. As a surrogate for plasma, and to ensure the studies were as minimally invasive as possible, isotope enrichment was measured in urine, as previously validated $(20,21)$. Enrichment reached plateau after $6 \mathrm{~h}$ as assessed by visual inspection of the data and an absence of any slope. Urine was collected in bags at each diaper change prefeed and either two or three hourly depending on the feeding protocol. Urine was stored frozen at $-20^{\circ} \mathrm{C}$ until analysis.

The doses of amino acid tracers were given to simulate a primed constant infusion as follows: ${ }^{15} \mathrm{~N}_{2}$-guanidino] arginine, $20 \mu \mathrm{mol} / \mathrm{kg}$ prime, followed by $40 \mu \mathrm{mol} / \mathrm{kg} / 2 \mathrm{~h}$ bolus or $60 \mu \mathrm{mol} / \mathrm{kg} / 3 \mathrm{~h}$ bolus; $\left[{ }^{15} \mathrm{~N}\right]$ proline, $20 \mu \mathrm{mol} / \mathrm{kg}$ prime, followed by $40 \mu \mathrm{mol} / \mathrm{kg} / 2 \mathrm{~h}$ bolus or $60 \mu \mathrm{mol} / \mathrm{kg} / 3 \mathrm{~h}$ bolus; and $\left[2,4,4,{ }^{2} \mathrm{H}_{3}\right]$ glutamate, $30 \mu \mathrm{mol} / \mathrm{kg}$ prime, followed by $60 \mu \mathrm{mol} / \mathrm{kg} / 2 \mathrm{~h}$ bolus or $90 \mu \mathrm{mol} / \mathrm{kg} / 3 \mathrm{~h}$ bolus. Each infant was studied once and the study lasted for $12 \mathrm{~h}$.

Isotopes. Isotopes were obtained from Cambridge Isotope Laboratories Inc. (Andover, MA). Three labeled amino acids were used: $\left[{ }^{15} \mathrm{~N}_{2}\right.$-guanidino] arginine (isotope enrichment $99.4 \%$, D-isomer $0.27 \%$ ), $\left[{ }^{15} \mathrm{~N}\right]$ proline $(98.7 \%$, $<0.5 \%)$, and $\left[2,4,4,{ }^{2} \mathrm{H}_{3}\right]$ glutamate $(97.1 \%,<0.5 \%)$.

Solutions of the tracer were prepared by the pharmacy, at The Hospital for Sick Children, in sterile water and stored at $4^{\circ} \mathrm{C}$ until use. The concentration of the solutions was arginine $30 \mathrm{mg} / \mathrm{mL}$, proline $25 \mathrm{mg} / \mathrm{mL}$, and glutamate 5 $\mathrm{mg} / \mathrm{mL}$. Solutions were confirmed to be sterile and pyrogen free before use.

Analysis of enrichment and chiral separation. Fifty microliters of urine were deproteinized by the addition of $500 \mu \mathrm{L}$ of methanol followed by centrifugation at $13,000 \times \mathrm{g}$ for $5 \mathrm{~min}$. The supernatant was dried under $\mathrm{N}_{2}$ and reconstituted in $0.1 \%$ formic acid. Isotope analysis was performed using an API 4000 triple quadrupole mass spectrometer (Applied Biosystems/MDS Sciex, Concord, Ontario, Canada) operated in positive electrospray ionization mode. This was coupled to an Agilent 1100 HPLC system (Agilent Technologies, Palo Alto, CA). All aspects of the system operation were controlled using the Analyst NT version 1.4.1 software (Applied Biosystems/MDS Sciex). Maximum sensitivity for $\mathrm{L}$ and $\mathrm{D}$ arginine, citrulline, ornithine, proline, and glutamate was achieved by measuring product ions multiple reaction monitoring from the fragmentation of the protonated $[\mathrm{M}+\mathrm{H}]^{+}$ molecules of each amino acid. Only the enrichments of the L-isoforms of the amino acids were analyzed for this study. The $[\mathrm{M}+\mathrm{H}]^{+}$precursor (parent) ion for each of the amino acids was $\mathrm{m} / \mathrm{z} 175.1$ for arginine, 116.1 for proline, 176.1 for citrulline, 133.1 for ornithine, and 148.1 for glutamate. The signal for the most abundant product (daughter) ions ( $\mathrm{m} / \mathrm{z} 70.1$ for arginine, 70.1 for proline, 70.1 for citrulline, 70.1 for ornithine, and 84.1 for glutamate) were also optimized. Chiral separations were performed with a Chirobiotic $\mathrm{T}$ (teicoplanin) HPLC column, $25 \mathrm{~cm} \times 4.6 \mathrm{~mm}, 5 \mu \mathrm{m}$ (Astec, Whippany, NJ) using an isocratic gradient with 95:5 (10 mM NH4Ac, $\mathrm{pH}=4.1):(2: 1 \mathrm{MeOH}$ : $0.1 \% \mathrm{FA}$ in ACN) buffer at $700 \mu \mathrm{L} / \mathrm{min}$. The injection volume was $20 \mu \mathrm{L}$ with an overall analysis time (injection to injection) of $35 \mathrm{~min}$.

The labeled [ ${ }^{15} \mathrm{~N}_{2}$-guanidino] arginine has a parent ion with $\mathrm{m} / \mathrm{z} 177.1$ and a daughter ion with $\mathrm{m} / \mathrm{z} 70.1$. Labeled $\left[{ }^{15} \mathrm{~N}\right]$ proline has a precursor ion with $\mathrm{m} / \mathrm{z}$ of 117.1 and a product ion of 71.1 . The respective ions for $\left[2,4,4,{ }^{2} \mathrm{H}_{3}\right]$ glutamate are 151.1 and 87.1.

The appearance of the proline and glutamate tracers in arginine was determined by measuring the precursor or product $\mathrm{m} / \mathrm{z}$ ion pair of $176 / 71$ for proline and 178/73 for glutamate. Similarly, the conversion of the labeled tracers into citrulline was determined using the precursor or product $\mathrm{m} / \mathrm{z}$ ion pair of 177.1/71 from proline and 179/73 from glutamate. The synthesis of ornithine from the tracers was assessed using the $\mathrm{m} / \mathrm{z}$ ion pairs of 134/71 from proline and 136/73 from glutamate.

Data analysis. Isotope enrichment was expressed as mole percent excess (MPE) calculated as enrichment at plateau minus the background measurement at baseline.

As it was not possible by the given study design and ethical constraints to give i.v. tracers to measure whole body flux, the turnover of the enterally infused amino acids was calculated using the equation:

$$
Q=i\left[\left(E_{i} / E_{u}\right)-1\right]
$$

where $Q$ is the turnover of the amino acid through the free amino acid pool, $i$ is the rate of infusion of the tracer, $E_{i}$ is the enrichment of the tracer in the infusion, and $E_{u}$ is the MPE of the tracer in urine at plateau.

The conversion rates of the infused isotopes to arginine was calculated by the formula

$$
Q_{\text {precursor-product }}=E_{\text {product }} / E_{\text {precursor }} \times Q_{\text {arginine }} .
$$

The fractional conversion of the infused isotopes to ornithine and citrulline was calculated by the formula:

$$
Q_{\text {precursor-product }}=E_{\text {product }} / E_{\text {precursor }} \text {. }
$$

Statistical analysis. Data are expressed as mean with SDs. Enrichment of amino acids above baseline was analyzed using Students $t$ test. Significance was assumed if $p<0.05$ ). Statistical analysis was performed using SAS version 9.1 (SAS Institute, Cary, NC). 
Table 2. Enrichment of labeled amino acids in plasma sampled in urine

\begin{tabular}{lcccc}
\hline & Mean MPE & SD & $\begin{array}{c}\text { Enteral turnover } \\
(\mu \mathrm{mol} / \mathrm{kg} / \mathrm{h})\end{array}$ & $\mathrm{SD}$ \\
\hline$\left({ }^{15} \mathrm{~N}_{2}\right.$ guanidino $)$ Arginine & 4.11 & 1.62 & 461 & 181 \\
$1-{ }^{15} \mathrm{~N}$ Arginine & 0.7 & 0.9 & & \\
$2,4,4-\mathrm{D}_{3}$ Arginine & $\mathrm{ND}$ & $\mathrm{ND}$ & & \\
$1{ }^{15} \mathrm{~N}$ Citrulline & 2.6 & 1.7 & & \\
$2,4,4-\mathrm{D}_{3}$ Citrulline & $\mathrm{ND}$ & $\mathrm{ND}$ & & \\
$1-{ }^{15} \mathrm{~N}$ Ornithine & 2.8 & 1.68 & & \\
$2,4,4-\mathrm{D}_{3}$ Ornithine & $\mathrm{ND}$ & $\mathrm{ND}$ & & \\
$1{ }^{15} \mathrm{~N}$ Proline & 7.7 & 1.9 & 237 & 58 \\
$2,4,4, \mathrm{D}_{3}$ Glutamate & $\mathrm{ND}$ & $\mathrm{ND}$ & - & - \\
\hline
\end{tabular}

ND, not detected at MPE $>0.1$ above baseline. $\mathrm{D}_{3}={ }^{2} \mathrm{H}_{3}$.

\section{RESULTS}

All infants completed the study, tolerated it well, and there were no adverse events. Enrichment was measured in urine of the isotopes for ${ }^{15} \mathrm{~N}_{2}$ arginine and ${ }^{15} \mathrm{~N}$ proline (Table 2). No enrichment was detected, in any infant, of the $\mathrm{M}+3[2,4,4$, $\mathrm{D}_{3}$ ] glutamate; there was no rise in the occurrence of this isomer over background. The appearance of label from the proline tracer in ornithine, citrulline, and arginine was observed in all infants.

The mean enrichment for the arginine tracer was $4.11 \%$ $( \pm 1.62 \%)$. This corresponds to an enteral turnover rate for arginine of $461 \mu \mathrm{mol} / \mathrm{kg} / \mathrm{h}( \pm 181 \mu \mathrm{mol} / \mathrm{kg} / \mathrm{h})$. The enrichment for the proline tracer was $7.7 \%( \pm 1.9 \%)$ corresponding to a turnover rate of $237 \mu \mathrm{mol} / \mathrm{kg} / \mathrm{h}( \pm 58 \mu \mathrm{mol} / \mathrm{kg} / \mathrm{h})$.

Table 2 shows the synthesis of arginine and its intermediaries, ornithine and citrulline, from the proline isotope. Synthesis of all three amino acids from proline was demonstrated with enrichment in ornithine of $2.8 \%$ (SD $\pm 1.68 \%$ ), citrulline of $2.6 \%$ ( $\mathrm{SD} \pm 1.7 \%$ ), and arginine of $0.7 \%$ ( $\mathrm{SD} \pm 0.9 \%$ ).

The fractional conversion of proline to ornithine was 0.36 and from proline to citrulline was 0.34 . The rate of conversion of proline to arginine was $42 \mu \mathrm{mol} / \mathrm{kg} / \mathrm{h}$. There was no $\mathrm{M}+$ 3 , or $\mathrm{M}+2$, isomer of any of the three amino acids above baseline in any infant, indicating no evidence of synthesis of these amino acids from enteral glutamate.

\section{DISCUSSION}

Given the low arginine content of human milk and implied high rate of arginine synthesis, the objective of this study was to document whether human infants are able to synthesize arginine and to clearly identify the dietary precursors. To our knowledge, this is the first multistable isotope study quantifying the metabolism of arginine in enterally fed human preterm infants. We have demonstrated that arginine and its intermediary metabolites, ornithine and citrulline, are synthesized from proline. Conversely, we have shown that there is no conversion in vivo of the carbon skeleton from dietary glutamate into arginine or its precursors as measured by this method. Clearly, in enterally fed human infants, proline is the major, if not the only, dietary precursor for arginine. This observation has significant implications when considering arginine requirements.
We know of no other potential dietary precursor for arginine; therefore, proline and arginine must be regarded as codependant, with arginine and proline requirements considered in reference to the sum of arginine and proline intake. Therefore, to the estimate of arginine requirements of 140 $\mathrm{mg} / \mathrm{kg} / \mathrm{d}(0.8 \mathrm{mmol})$, the proline requirement of $180 \mathrm{mg} / \mathrm{kg} / \mathrm{d}$ $(1.56 \mathrm{mmol})$ must be added (assuming a proline content of protein of $9 \%$ and $2 \mathrm{~g} / \mathrm{kg} / \mathrm{d}$ net protein synthesis), suggesting a total molar requirement for arginine plus proline of 2.4 $\mathrm{mmol} / \mathrm{kg} / \mathrm{d}$. The sum of the molar content of arginine $(0.26$ $\mathrm{mmol} / \mathrm{g}$ protein) and proline $(0.74 \mathrm{mmol} / \mathrm{g}$ protein) in human milk is $1 \mathrm{mmol} / \mathrm{g}$ protein (22), which implies a protein intake of $2.4 \mathrm{~g} / \mathrm{kg} / \mathrm{d}$ to provide the estimated requirement of arginine and proline. Then, it follows that arginine or proline intake is likely inadequate during periods of the NICU stay as this level of protein intake for preterm infants cannot be met with human milk until full feeds are established and fully fortified. These observations suggest that the low arginine documented in preterm infants (7) relates to inadequate intake of proline and arginine. Whether this is clinically important with either short- or long-term effects is unknown.

The enteral turnover measurements of arginine and proline in our study are the first to be published for healthy growing preterm infants; therefore, it is necessary to discuss our results with reference to adult human studies and piglet studies as a model for the preterm infant. The arginine rate determined in our study $(460 \mu \mathrm{mol} / \mathrm{kg} / \mathrm{h})$ is considerably higher than that calculated by Castillo et al. (9), who measured an arginine flux of $125 \mu \mathrm{mol} / \mathrm{kg} / \mathrm{h}$ by using an i.v. tracer in infants recovering from persistent pulmonary hypertension of the newborn. Given the substantial metabolism of arginine by the splanchnic organs, which is estimated to be as high as $50 \%$ in piglets (23) and between 31 and 38\% in adult humans (24), the rate in our study was expected to be higher. However in the study by Castillo et al. (9), the infants were more mature, being born at term, were recovering from significant pulmonary hypertension, and were being fed smaller amounts of protein (1.2 $\mathrm{g} / \mathrm{kg} / \mathrm{d}$ ) and energy $(70 \mathrm{kcal} / \mathrm{kg} / \mathrm{d})$ when compared with this study in which infants were completely enterally fed receiving $\sim 160 \mathrm{~mL} / \mathrm{kg} / \mathrm{d}$ of milk.

Our estimate of turnover for enteral arginine of $460 \mu \mathrm{mol} /$ $\mathrm{kg} / \mathrm{h}$ is higher than the value in adults, in whom the turnover rate of intragastric arginine was estimated to be $\sim 120 \mu \mathrm{mol} /$ $\mathrm{kg} / \mathrm{h}$ (24). The higher rate in premature neonates compared with adults can be explained by the higher rate of endogenous protein turnover in newborns, which may be as much as $4-6$ times greater than that of adults $(25,26)$ and the increased requirement for arginine to meet the metabolic demands of growth.

The enteral proline turnover rate determined in our study is $237 \mu \mathrm{mol} / \mathrm{kg} / \mathrm{h}( \pm 58 \mu \mathrm{mol} / \mathrm{kg} / \mathrm{h})$. There are no comparable data in either human infants or adults. The only available data in humans is i.v. tracer whole body flux rates from a series of studies by Jaksic et al. (27-29), who determined a flux of proline of $70-75 \mathrm{~mol} / \mathrm{kg} / \mathrm{h}$ in healthy adults. The ratio between enteral arginine turnover in premature infants (460 $\mu \mathrm{mol} / \mathrm{kg} / \mathrm{h})$ and i.v. arginine flux in adults $(120 \mu \mathrm{mol} / \mathrm{kg} / \mathrm{h}$, 23 ) is $3.8: 1$. By comparison, the ratio of enteral proline 
turnover in infants $(237 \mu \mathrm{mol} / \mathrm{kg} / \mathrm{h})$ to i.v. proline flux in adults $(70 \mathrm{~mol} / \mathrm{kg} / \mathrm{h}, 25-27)$ is $3.4: 1$. This similarity suggests that the pattern of metabolism of the two amino acids, i.e. rate of absorption and metabolism by splanchnic organs occurs in similar proportion. However, animal data would suggest that only a small proportion, at most $14 \%$, of proline is extracted by the splanchnic organs (30) compared with a value of 50\% for arginine. The similarity in this ratio for arginine and proline suggests that the splanchnic metabolism of proline in humans may be much higher than previously believed and deserves further investigation to elucidate the proline requirements for the splanchnic organs and whether it is required for protein synthesis alone, amino acid precursor, or other metabolic roles.

Of note, in our estimates of enteral turnover, for both arginine and proline, is the considerable variation among subjects, which is greater for arginine than proline reflecting the multiple metabolic roles for arginine, notably creatine and NO synthesis. The source of this variation is likely multifactorial. It is well recognized that protein turnover rates in preterm infants are much higher than adults and show considerable variation among individuals. For example, Denne et al. (25), in infants of similar weight to those in our study (1.55 \pm $0.34 \mathrm{~kg}$ ), reported whole body protein synthesis rates of 10.5 $\mathrm{g} / \mathrm{kg} / \mathrm{d}$ but with a SD of $3 \mathrm{~g} / \mathrm{kg} / \mathrm{d}$. Protein synthesis is the largest component of arginine flux, and therefore, this likely explains the variation observed in our study. In addition, and by necessity, it was not possible to standardize feeds in this study beyond feed volume, and therefore, variation in nutrient intake will have contributed to the overall variation. Infants in our unit are considered to be at full feeds at $160 \mathrm{~mL} / \mathrm{kg} / \mathrm{d}$. The milk of choice is expressed breast milk to which fortifier is added when preterm infants reach full feeds. The amount of protein and arginine in breast milk also displays considerable variation. Montagne et al. (31) demonstrated that in the mature milk of mothers whose babies were born prematurely, the amount of protein varied by $\sim 20 \%$ with the variation being even greater when the infants were younger.

The arginine intake in infants who are fed breast milk has been estimated to be $45 \mathrm{mg} / \mathrm{kg} / \mathrm{d}$ (4) notwithstanding the variation described above. This equates to an intake of $\sim 10$ $\mu \mathrm{mol} / \mathrm{kg} / \mathrm{h}$. By comparison, our results indicate an arginine synthesis rate of $44 \mu \mathrm{mol} / \mathrm{kg} / \mathrm{h}$ from proline, indicating de novo arginine synthesis provides more arginine than is derived from breast milk and is equivalent to $\sim 198 \mathrm{mg} / \mathrm{kg} / \mathrm{d}$. This amount would account for the $160 \mathrm{mg}$ of arginine per $\mathrm{kg} / \mathrm{d}$ required to support protein synthesis and hence growth. This is also true in the piglet, in which arginine intake in sows' milk meets only $1 / 4$ of the estimated metabolic requirement for arginine (32). There are no human data with which to compare the fractional synthesis rates of ornithine and citrulline; however, these are similar to the synthesis rates reported for the piglet (33).

We did not measure any glutamate tracer in the urine glutamate pool. Recognizing that this was a possibility because of high dilution from dietary and endogenous glutamate, we dosed more on a per $\mathrm{kg}$ body weight basis than the other tracers. Because glutamate has a relatively low solubility, we estimated that this was the maximum dose of glutamate that could be given enterally to the infants without risk of inducing feed intolerance. Similarly, we chose the glutamate isotope as $\mathrm{M}+3$, which is present naturally at only low amounts and thus would allow us to detect lower levels of enrichment. It is possible that absorption of free intraluminal glutamate may have been incomplete; however, this is an unlikely explanation as enrichment of the arginine and proline tracers was significant, and in piglets, it has been demonstrated that almost all enteral glutamate is absorbed and subsequently metabolized by the small intestine (34). A further possible reason for the lack of enrichment of the glutamate pool is that of proton substitution. This happens when a labeled deuterium atom is replaced by an unlabeled proton. This is an unlikely explanation in this case because the isomer used was $\left[2,4,4, \mathrm{D}_{3}\right]$ glutamate, and these deuterium atoms are unlikely to be spontaneously replaced because of their location on the molecule. For example, studying deuterium exchange in arginine, Huang et al. (34a) demonstrated that this took place mostly at the carboxyl group and to a lesser extent on the amino $\mathrm{N}$ atom. By studying leucine metabolism using two tracers, one carbon the other deuterium labeled, Hoerr et al. (35) found no evidence of deuterium substitution. However, in case there was systematic proton substitution, we also looked for $\mathrm{M}+2$ and $\mathrm{M}+1$ isomers of glutamate but found no enrichment over baseline (data not shown). Despite the lack of evidence that deuterium substitution may be occurring, the use of a carbonlabeled tracer would circumvent the issue and also allow measurement of oxidation.

Notwithstanding these issues, we conclude that as there was no measurable enrichment of glutamate, it is clear that enterally supplied glutamate is entirely metabolized by the splanchnic organs on first pass. This is in keeping with the findings of others that there is a substantial metabolism of glutamate and glutamine by the gut $(30,34,36)$.

Although there was no enrichment of the urine glutamate pool from the enteral glutamate tracer, if there had been significant synthesis of arginine and intermediaries from glutamate in the splanchnic tissues, we would have detected $\mathrm{M}+$ 3 isomers of these amino acids. However, no $\mathrm{M}+3$ isomers of arginine, ornithine, or citrulline were detected above baseline in any infant. Moreover, to ensure no systematic deuterium substitution, $\mathbf{M}+2$ isomers of arginine, citrulline, and ornithine were looked for but not found (data not shown). Therefore, although it is clear that P5C synthase is present in piglet enterocytes (18) and that arginine may be synthesized from glutamine in isolated enterocytes (18), there is negligible, or undetectably low, synthesis of arginine from dietary glutamate in healthy growing preterm infants in vivo, despite the significant metabolism of glutamate by the splanchnic organs. We hypothesize that in the neonatal enterocyte in vivo that the carbon chain of glutamate is used primarily as an energy source and is rapidly oxidized (36) with the nitrogen atom either excreted or used through transamination.

The main finding in our study is that the dietary precursor for arginine is proline, with no synthesis from glutamate. This is consistent with our work using the neonatal pig in which we have demonstrated, using a number of dietary approaches 
$(14,15,37,38)$, that arginine can only be synthesized from proline through citrulline and that there is no in vivo synthesis from enteral glutamate.

\section{REFERENCES}

1. Carcillo JA 2003 Does arginine become a "near" essential amino acid during sepsis? Crit Care Med 31:657-659

2. Zello GA, Menendez CE, Rafii M, Clarke R, Wykes LJ, Ball RO, Pencharz PB 2003 Minimum protein intake for the preterm neonate determined by protein and amino acid kinetics. Pediatr Res 53:338-344

3. Morris SM Jr 2004 Enzymes of arginine metabolism. J Nutr 134:2743S-2747S

4. Svanberg U, Gebre-Medhin M, Ljungqvist B, Olsson M 1977 Breast milk composition in Ethiopian and Swedish mothers. III. Amino acids and other nitrogenous substances. Am J Clin Nutr 30:499-507

5. Batshaw ML, Wachtel RC, Thomas GH, Starrett A, Brusilow SW 1984 Arginineresponsive asymptomatic hyperammonemia in the premature infant. J Pediatr 105:86-91

6. Heird WC, Nicholson JF, Driscoll JM Jr., Schullinger JN, Winters RW 1972 Hyperammonemia resulting from intravenous alimentation using a mixture of synthetic 1-amino acids: a preliminary report. J Pediatr 81:162-165

7. Wu G, Jaeger LA, Bazer FW, Rhoads JM 2004 Arginine deficiency in preterm infants: biochemical mechanisms and nutritional implications. J Nutr Biochem 15:442-451

8. Zamora SA, Amin HJ, McMillan DD, Kubes P, Fick GH, Butzner JD, Parsons HG, Scott RB 1997 Plasma L-arginine concentrations in premature infants with necrotizing enterocolitis. J Pediatr 131:226-232

9. Castillo L, DeRojas-Walker T, Yu YM, Sanchez M, Chapman TE, Shannon D, Tannenbaum S, Burke JF, Young VR 1995 Whole body arginine metabolism and nitric oxide synthesis in newborns with persistent pulmonary hypertension. Pediatr Res 38:17-24

10. Amin HJ, Zamora SA, McMillan DD, Fick GH, Butzner JD, Parsons HG, Scott RB 2002 Arginine supplementation prevents necrotizing enterocolitis in the premature infant. J Pediatr 140:425-431

11. McCaffrey MJ, Bose CL, Reiter PD, Stiles AD 1995 Effect of L-arginine infusion on infants with persistent pulmonary hypertension of the newborn. Biol Neonate 67:240-243

12. Wu G, Davis PK, Flynn NE, Knabe DA, Davidson JT 1997 Endogenous synthesis of arginine plays an important role in maintaining arginine homeostasis in postweaning growing pigs. J Nutr 127:2342-2349

13. Windmueller HG, Spaeth AE 1981 Source and fate of circulating citrulline. Am J Physiol 241:E473-E480

14. Brunton JA, Bertolo RF, Pencharz PB, Ball RO 1999 Proline ameliorates arginine deficiency during enteral but not parenteral feeding in neonatal piglets. Am J Physiol 277:E223-E231

15. Bertolo RF, Brunton JA, Pencharz PB, Ball RO 2003 Arginine, ornithine, and proline interconversion is dependent on small intestinal metabolism in neonatal pigs. Am J Physiol Endocrinol Metab 284:E915-E922

16. Wilkinson DL, Bertolo RF, Brunton JA, Shoveller AK, Pencharz PB, Ball RO 2004 Arginine synthesis is regulated by dietary arginine intake in the enterally fed neonatal piglet. Am J Physiol Endocrinol Metab 287:E454-E462

17. Murphy JM, Murch SJ, Ball RO 1996 Proline is synthesized from glutamate during intragastric infusion but not during intravenous infusion in neonatal piglets. J Nutr $126: 878-886$

18. Wu G, Knabe DA 1995 Arginine synthesis in enterocytes of neonatal pigs. Am J Physiol 269:R621-R629
19. Ligthart-Melis GC, van de Poll MC, Dejong CH, Boelens PG, Deutz NE, van Leeuwen PA 2007 The route of administration (enteral or parenteral) affects the conversion of isotopically labeled L-[2-15N]glutamine into citrulline and arginine in humans. JPEN J Parenter Enteral Nutr 31:343-348; discussion 349-350

20. Wykes LJ, Ball RO, Menendez CE, Pencharz PB 1990 Urine collection as an alternative to blood sampling: a noninvasive means of determining isotopic enrichment to study amino acid flux in neonates. Eur J Clin Nutr 44:605-608

21. Tomlinson C, Rafii M, Ball RO, Pencharz P 2010 The significance of d-isomers in stable isotope studies in humans is dependent on the age of the subject and the amino acid tracer. Metabolism 59:14-19

22. Davis TA, Nguyen HV, Garcia-Bravo R, Fiorotto ML, Jackson EM, Lewis DS, Lee DR, Reeds PJ 1994 Amino acid composition of human milk is not unique. J Nutr 124:1126-1132

23. Urschel KL, Shoveller AK, Uwiera RR, Pencharz PB, Ball RO 2006 Citrulline is an effective arginine precursor in enterally fed neonatal piglets. J Nutr 136:1806-1813

24. Castillo L, Chapman TE, Yu YM, Ajami A, Burke JF, Young VR 1993 Dietary arginine uptake by the splanchnic region in adult humans. Am J Physiol 265:E532E539

25. Denne SC, Karn CA, Liechty EA 1992 Leucine kinetics after a brief fast and in response to feeding in premature infants. Am J Clin Nutr 56:899-904

26. Pencharz P, Beesley J, Sauer P, Van Aerde J, Canagarayar U, Renner J, McVey M, Wesson D, Swyer P 1989 A comparison of the estimates of whole-body protein turnover in parenterally fed neonates obtained using three different end products. Can J Physiol Pharmacol 67:624-628

27. Jaksic T, Wagner DA, Young VR 1990 Plasma proline kinetics and concentrations in young men in response to dietary proline deprivation. Am J Clin Nutr 52:307-312

28. Jaksic T, Wagner DA, Burke JF, Young VR 1991 Proline metabolism in adult male burned patients and healthy control subjects. Am J Clin Nutr 54:408-413

29. Jaksic T, Wagner DA, Burke JF, Young VR 1987 Plasma proline kinetics and the regulation of proline synthesis in man. Metabolism 36:1040-1046

30. Bertolo RF, Burrin DG 2008 Comparative aspects of tissue glutamine and proline metabolism. J Nutr 138:2032S-2039S

31. Montagne P, Cuilliere ML, Mole C, Bene MC, Faure G 1999 Immunological and nutritional composition of human milk in relation to prematurity and mother's parity during the first 2 weeks of lactation. J Pediatr Gastroenterol Nutr 29:75-80

32. Wu G, Meininger CJ, Knabe DA, Bazer FW, Rhoads JM 2000 Arginine nutrition in development, health and disease. Curr Opin Clin Nutr Metab Care 3:59-66

33. Urschel KL, Rafii M, Pencharz PB, Ball RO 2007 A multitracer stable isotope quantification of the effects of arginine intake on whole body arginine metabolism in neonatal piglets. Am J Physiol Endocrinol Metab 293:E811-E818

34. Reeds PJ, Burrin DG, Stoll B, Jahoor F 2000 Intestinal glutamate metabolism. J Nutr 130:978S-982S

34a.Huang Y, Marini JA, McLean JA, Tichy SE, Russell DH 2009 A mechanistic study of the H/D exchange reactions of protonated arginine and arginine-containing di- and tripeptides. J Am Soc Mass Spectrom 20(11):2049-2057

35. Hoerr RA, Matthews DE, Bier DM, Young VR 1991 Leucine kinetics from [2H3]and [13C]leucine infused simultaneously by gut and vein. Am J Physiol 260:E111E117

36. Riedijk MA, de Gast-Bakker DA, Wattimena JL, van Goudoever JB 2007 Splanchnic oxidation is the major metabolic fate of dietary glutamate in enterally fed preterm infants. Pediatr Res 62:468-473

37. Murphy SJ, Murphy JM, Ball RO 1996 Proline is synthesized from intravenously infused arginine by piglets consuming low protein diets. Can J Anim Sci 76:435441

38. Urschel KL, Wilkinson CW, Pencharz PB, Ball RO 2007 Coadministration of ornithine and alpha-ketoglutarate is no more effective than ornithine alone as an arginine precursor in piglets enterally fed an arginine-deficient diet. J Nutr 137:55-62 